\title{
HUNGARY AND THE BALKANS
}

As regards the Balkans, Hungary is one of the intermediary regions in Europe. At the same time, the Balkans is the tie-up territory between Turkey, one of the emerging regions today, and Hungary, which aims to cooperate with it. Being a NATO and EU member state it takes part in the geopolitical games that are played between the EU, Russia, the USA and some of the countries of the Islamic world. These dealings fundamentally determine tasks in Hungarian foreign policy, cultural policy, economic policy, security- and defence policy for the forthcoming decades.

Hungary acts as a gate between Western Europe and the Balkans. This role used to be more dominant in previous centuries of Hungarian history than it is today, not least because the country's size and strength significantly decreased after the Trianon Treaty. Many of the historical, imperial reflexes have remained, but without any imperial gravity. Today we are just one of the intermediary regions that have relations with the Balkans and form a bridge to Europe. The accelerated alteration in the world order, the BRICS countries and the emergence of some important middle-sized states, such as Turkey, make adaptation inevitable for our country. This is what the policy of "Eastern opening" is about.

Key words: Hungary, Balkans, geopolitics, migration, Danube, Eastern opening

\section{Introduction}

Throughout Hungarian history the Balkans has always been an ineludible reference point and seemingly this will remain so. Here is what László Makkai wrote about this from a historical perspective:

"For a millennium Hungary played the role of a lock and the gate between the Balkans and Western Europe. There were times when the small states of the Balkans found their political chances of existence under the wing of the strong Hungarian power, but there were no times when Hungary was a negligible factor

Dr. Norbert PAP, PhD, MA, Msc, Associate professor, Institute of Geography, University of Pécs, Hungary, e-mail: pnorbert@gamma.ttk.pte.hu

** Máté Kitanics, MA, Msc, PhD candidate of the Institute of Geography, University of Pécs, Hungary, e-mail: kitanics1@gmail.com 
in their lives. During the first five centuries of Hungarian history it often seemed that the Balkans would become Hungary, whereas in the second half of the millennium we saw the Balkans penetrating deeply into the territory of Hungary (MAKKAI, L. 1942)."”

The quote requires a short explanation. A major direction of political and territorial intentions during the first centuries after the foundation of the Kingdom of Hungary pointed toward south, in the direction of the Balkan Peninsula. As a result of conquest, from 1102 Croatia was a part of the Kingdom of Hungary, and from the early 12 th century to the 15 th century Dalmatia also recognised the rule of the Hungarian kings. The role of the weakening Byzantine Empire in the Balkan Peninsula was gradually taken over by Hungary from the 13th century. With the expansive Hungarian foreign policy, in the 12-13th centuries numerous banates (administrative units lead by the "ban", also called viceroy) were formed at the southern border territories of Hungary with a protective purpose, at the expense of the peoples of the Balkans. Although this puffer zone protected our kingdom, it is very clear that the economic and military capacity of the Kingdom of Hungary - considered a mid-size power at the time - was only enough to control the northern parts of Bosnia and Serbia and the northwestern part of the region, later called Wallachia. The Hungarian state could not extend its action radius to the inner parts of the Balkan Peninsula, and sometimes maintaining its rule over this southern protective area and Croatia also caused major hardships (Kitanics, M. 2008).

During the mid-14th century a new power appeared on the Balkan Peninsula, rapidly expanding, disrupting existing political relations and restructuring them according to its own interests. From 1354 to the first decade of the 16th century the Ottoman Empire did not only conquer the states of the Balkans, but also destroyed the puffer zone of the Kingdom of Hungary. It then entered the central territory of Hungary via the old military road (Via militaris, Istanbul Road), the Morava gate, and only pulled back at the end of the 17th century, due to changes in the balance of power. All these caused major waves of migration in the 15-18th centuries, causing major transformations in the ethnic layout of the Carpathian-Balkan region. The migration movements through the migration channels in the Balkans (Figure 1) were two-way. During the Turkish conquest in the Balkan Peninsula, large numbers of refugees arrived, who sought refuge within the territory of the Kingdom of Hungary. A major part of them, joined by members of the indigenous population, migrated to the shrunken territory

$1 \quad$ „Egy évezred óta a Balkán és Nyugat-Európa között Magyarország a zsilip és a kapu szerepét játszotta. Volt idő, mikor a magyar nagyhatalom szárnyai alatt találták megpolitikai életlehetöségeiket aBalkán kis államai, de nem volt idö, mikor Magyarország ne lett volna tényezö életükben. Történelmünk elsö félezer éve alatt többször látszott úgy, hogy a Balkánból Magyarország lesz, a második félezer év során viszont az események úgy hozták, hogy a Balkán nyomult bele mélyen Magyarország testébe (MAKKAI, L. 1942).” 
of the Kingdom of Hungary after the Ottomans entered the Carpathian Basin. Then the Ottoman Empire brought its subjects from the Balkans to the low population density areas for military and economic purposes, while many people also moved there due to spontaneous migration. The situation that existed till 1683-84 changed fundamentally when the Turks pulled back. With the ethnic Turkish administrative personnel, soldiers and traders, many Islamized people, mostly from the Balkans and/or primarily Orthodox people in the service of the Ottoman Empire left the Carpathian Basin.

The land stretching from the current borders of Hungary to the former border of the Hungarian Kingdom (Orsova) features an intricate spatial texture which bears the marks of our former political, economic and social aspirations creating the most important reference space for us in the Balkan region. This has been and probably will continue to be the most important zone providing us some elbow-room. This is the filter that sifted and still does the Balkan influences, as well as those transmitted from Hungary and the Central European region in the opposite direction. In the future Hungarians will be able to gain the experience related here to the wider region. This is the reason why this region deserves to have special attention paid to it in Hungarian foreign policy. At the same time we are faced with having insufficient social knowledge of it.

Figure 1: Migration channels in the Balkans from the Romans to the $18^{\text {th }}$ century.

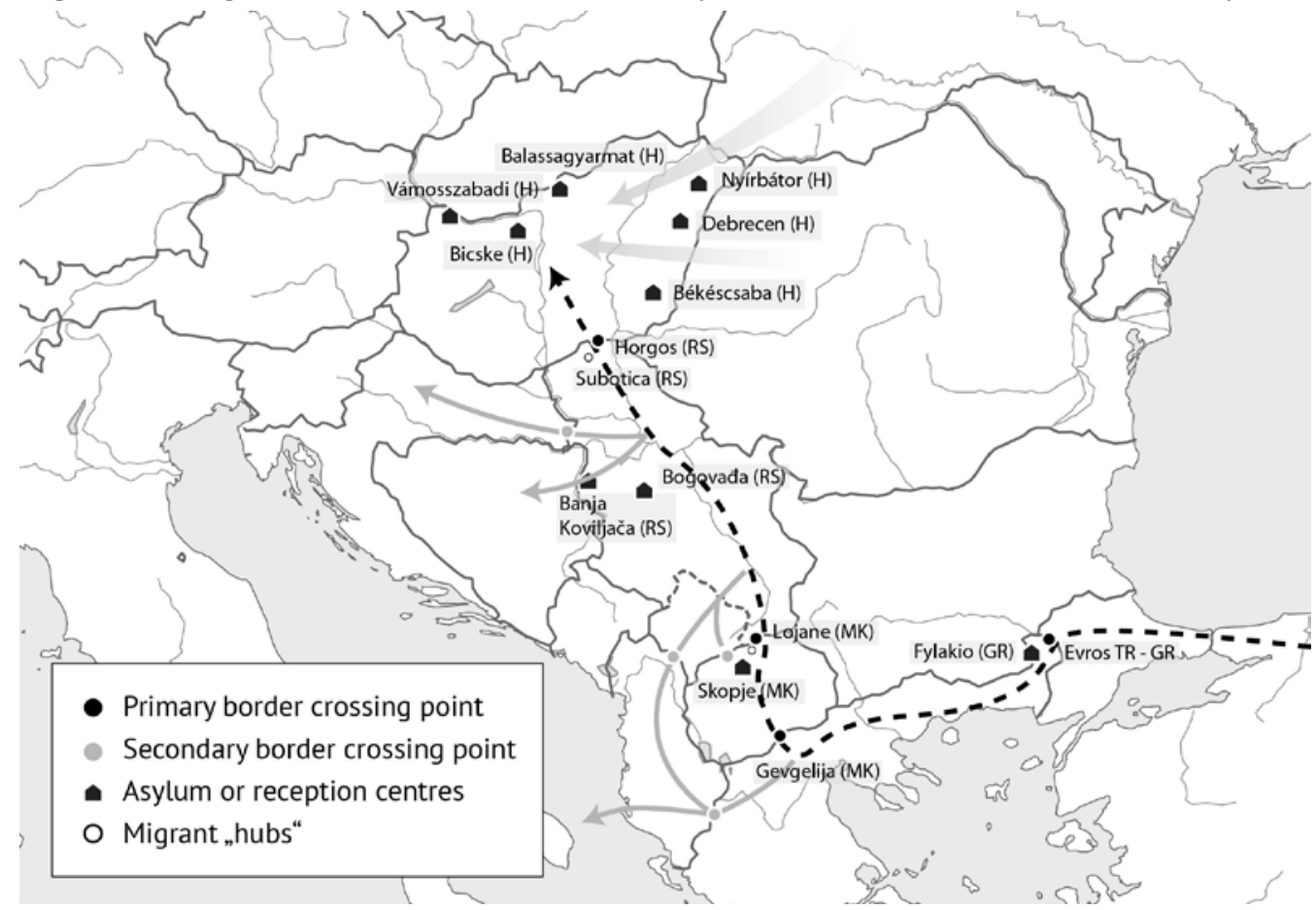


Today Hungary must reckon with simultaneous disintegration and integration in this region. Our country, as a member of a greater political community, is striving for the evolution from "the Balkans" into "Europe". The disintegration of the Yugoslav region may not have ended yet; the national integration aspirations are determinant, but at the same time the supranational integration processes (NATO, EU) are also present and intensifying. Hungary occupies a key strategic position even today. Efforts made during Hungary's EU presidency played a major part in the EU-accession of Croatia. Maintaining good relationships with Hungarians is of vital importance to Serbia, as has been shown in the issue of the Restitution Law. As an economic partner, we play a major role for the smaller Balkan states as well. Today Hungary might not be the only "lock and gate" of the region, nevertheless we are still one of the numerous.

\section{Hungary's Balkan policy today}

Since the regime change, public opinion in Hungary has regarded the Balkans as a region that from time to time poses a threat to the country and its citizens. However, it comprehends little of the intricate territorial processes and shows practically no interest in them. Public opinion in Hungary generally demonstrates little if any interest in foreign affairs, some extraordinary events might draw some publicity at best, and even compared to this the Balkans is of peripheral significance in the priority system. Thus, Hungarian foreign policy carries a dissolved antagonism in terms of the representation of Hungarian interests and their political and social perception.

Interest shown by the Hungarian business sector has increased, some corporations having established a strong position in the region. However, this has little social and national economic impact. Small- and medium-sized enterprises are mainly active in the borderland populated partly by Hungarians, and do not exploit market opportunities as they arise.

The activity of the civil society is even weaker. The degree of cooperation motivated by the tendering system is low and generally characterized by low efficiency. In Hungarian higher education and in academic circles researches on the Balkans suffer from shortage of workshops and resources. Furthermore, their structure is inappropriate, resulting in prevalence of primarily historical studies.

It is generally true that we have come to realize that major problems are brought about from the Balkans, but that there are also opportunities that should be responded to. Nevertheless, in the last twenty years only faint attempts have followed this realization. The Balkans comprise an issue for some small elites from the spheres of politics, economics, and state administration, but even these elite groups give little priority to this issue. For the most part it is of high priority only for the organizations specialized in national security and defence.

Following the regime change Hungarian governments were compelled to deal with the Balkan issues as well. This mainly meant addressing security 
challenges, which was motivated by constraint. No forward-looking, coherent strategy has been drawn up until recently. The approaches of the right- and left-wing governments to the issue seem to differ. Left-wing cabinets have typically attached lesser importance to it and they have generally focused merely on following the events. This has partly been due to the fact that the Bosnian and Croatian war and the conflict in Kosovo started during the right-wing governance $(1990-94 ; 1998-2002)$ and required instant response. ${ }^{2}$ However, irrespective of the conflict-stricken periods, it is a fact that it was the right-wing that took interest in the Hungarian communities living in the area and stood up firmly for them. In the last two decades this has been condensed in supporting the issue of dual citizenship and autonomy aspirations.

The Balkan policy of the centre-right government in power since 2010 is worded in two strategic documents. One of these is entitled "Hungarian Foreign Policy after the EU Presidency" ${ }^{3}$ and the other is "Hungary's National Security Strategy" 1035/2012. Both documents specify and devote special attention to this region.

The strategy on foreign policy mentions the Western Balkans specifically, listing all of its states one by one and the Hungarian policy related to them, including security policy considerations. It describes separately the cooperation related to the Danube Strategy and Hungary's role played in it; on the following pages Bulgaria and Romania are both present, but mentioned respectively. The Black Sea region is referred to in connection with the latter two, and the Caucasus as well as the transmission land beyond it bearing great energetic significance. This region is bordered to the north by the countries of the "Visegrad Group".

In the strategy on national security, the chapter entitled "Regional Conflicts" deals with the region, which is also alluded to with reference to the "Eastern and Southern" territories, where national security might be threatened by the risk of conventional armed conflicts, organized crime and terrorism. In the Southern territories there are Hungarian ethnic populations, furthermore, states that have not integrated into NATO or the EU, the Euro-Atlantic policy of which we should promote. Euro-Atlantic values are rated rather differently in each state, modernization and other processes aiming at a regime change are slow, corruption is interwoven into the society and the economy, and there are a great number of unresolved ethnic, religious and minority problems. This environment serves as a breeding-ground for terrorism and organized crime, and facilitates the operation of various smuggling groups. The strategy concludes

The operation known as 'The Storm' /“Oluja” in the summer of 1995 was launched during the governance of the Socialist - Free Democrat "Horn" cabinet. Neither the declaration of Montenegro's independence in 2006 and that of Kosovo in 2008, nor even the constitutional crisis in Bosnia provoked a war-like trauma, so that Hungarian reactions were not particularly emphatic: they typically reflected the commitment to the Atlantic.

Hungarian Foreign Policy after the EU Presidency, Budapest, Ministry of Foreign Affairs, 2011.

Vol. 11, No 4, 2014: 219-240 
that in the territories not yet integrated, an international presence, especially, that of the EU might be justified, even in the long run.

Both documents presume an improving situation, intensifying stability, still vindicating that there are unresolved interstate and other political problems, which however can be treated with international presence; the relevant major security threat is not prevalent at the state level. It is the terrorist organizations gaining ground in the neighbourhood and organized crime that might generate the greatest problem in the future.

The documents reflect a strong commitment to the West; the shared values of the European Union community and Atlanticism are highlighted in them. The two materials are presented as governmental and professional statements of opinion, but neither do the Hungarian political parties have harsh debates, nor is there the policy to be followed regarding the region. There have been slight disagreements at the very most concerning the assessment of the status of the Hungarians in Vojvodina.

\section{The Danube region policy}

The Danube as a transportation, innovation and symbolic corridor connects us not only with the central - German - part of Europe; its relevance has for centuries been determinant southwards as well. The Danube, flowing into the Black Sea on the Northern edge of the Balkans, made its way into Hungarian foreign political thinking through the work of István Széchenyi ${ }^{4}$.

We made great sacrifices for the sake of its navigability once, and for long it remained a high priority in our thinking. Navigation does not have the significance it used to have, but in the EU there are efforts made to improve the conditions of cargo shipping. For the EU the significance of the Danube increased in the wake of the EU enlargements in 2004 and 2007. The impacts of climate change, the environmental risks and the growing demand for fresh water also direct our attention to the river and its water system. The European Commission endorsed the macro-strategy for the Danube Region during the Hungarian EU presidency. Hungary must also reconsider its interests in the Balkans and its policy for the forthcoming years in the framework of the Danube strategy.

It is not over the last quarter of a century following the regime change that disagreements concerning Hungary's role-taking have developed, but over a much longer period, until they have finally taken shape as a result of continued internal and external influences. With respect to the Balkans, we find it expedient to consider the wider environment with special emphasis on the processes in Southern Europe and the Mediterranean region and their ever-changing

$4 \quad$ Count István Széchenyi (1791-1860), a Hungarian aristocrat, who had a prominent role in the modernization process in the nineteenth century Hungary. He attached great importance to the navigability of the Danube to promote Hungary's joining the world market as an international waterway. His name is associated with the regulation of the River Danube and the launch of steam boating. 
roles. What are the enduring factors in our external environment and in the Hungarian mentality related to the outside world that shape and define our foreign political goals and margins?

\section{Political geographical issues of Hungary's foreign relations and their impact on the Balkans}

\section{Hungarian particularity}

In the circles of Hungarian intellectuals from time to time there are blazing rows in connection with "Europeanness" and Hungary's position in Europe. Geographically, Budapest is situated $2400 \mathrm{~km}$ from the northernmost point of Norway - "Nordkap", $2500 \mathrm{~km}$ from the westernmost point of Europe - Cabo da Roca, $2700 \mathrm{~km}$ from the Urals, while only $1300 \mathrm{~km}$ from the southernmost tail of Greece - Cape Matapan. Based on this data, it becomes obvious that Hungary is situated in the southern part of Central Europe.

The debate does not revolve around physical distances, but rather around Hungarian particularity on the one hand, and our "relative place" on the other (KIss, J. L. 2003). The debate over particularity is related to ethno-genesis and states that the land taking "Magyars" of Asian origin - who had already assimilated a great variety of ethnic groups during their migration - harboured numerous migrants (Eastern peoples and Western "guest" communities - "hospes") after having settled in the homeland, thus evolving into the now existing anthropological and cultural body politic. The "Magyars" preserved their Finno-Ugric language from the times prior to the land taking, together with their folk culture laden with the Turkic influences of the steppe. Having done so, they became insulated in the circumambient sea of Indo-European (largely Slavic) languages. The main foreign political consequence of our linguistic particularity is that due to lack of foreign language skills, the Hungarians are integrated in the globalized world to a rather small degree, having limited insight into and understanding of its events ${ }^{5}$.

In areas lying to the south and south-east of Hungary our otherness is referred to and perceived at times with a positive, and at other times with a negative connotation. The aforementioned primeval cultural layers play a significant role in the markedly positive, friendly Turkish-Hungarian relations. The roots of the similarly good, problem-free Bulgarian-Hungarian, BosnianHungarian and Albanian-Hungarian relations trace back to shared medieval

5 On a demotic level this applies less to some torn off regions - particularly to Transylvania - than to the mother country, as Hungarians beyond the borders have to learn the official language through which they are linked to the world of other Slavic or Neo-Latin languages. Furthermore, it is also true that, with the exception of Ukraine, English is taught more effectively than here in all neighbouring countries. 
historical events. Neighbour relations between Croatia and Hungary but more typically Serbia and Hungary are a lot more controversial, primarily due to the events of the nineteenth and twentieth centuries.

\section{Spatial community and neighbourhood policy}

In essence, the issue of "place" belongs to the spatial community, i.e.in this case it refers to the question of which countries should Hungary co-exist in cooperation with among the peoples of Europe, and respectively, what kind of role it should basically play (see: as it is often called: the bulwark of the West, the ferrycountry, the Westernmost East, the Easternmost West, etc.). In this issue the positive consensus was mostly embodied in the fact that the country belonged to the community of Central European nations. While in the state socialist era this meant a qualitative category - compared to the much more disadvantageous regions of the Soviet Empire living under more difficult conditions - this connotation vanished with the dissolution of the Soviet Union. In the 1990s the European Union became the targeted community and this wish materialized in 2004.

Spatial community could be positively grounded, and in fact it is partly grounded on the co-existence during the Austro-Hungarian Monarchy and the positive experience gained in the times of dualism. Unfortunately, however, the evaluation of this period shows contradictions: the current Romanian and Slavic states of the region were formed at the Monarchy's expense; the sum of the state-founding elites showed animus towards it (GuLYás, L. 2012). Everrenascent small-nation nationalisms impeach common grounds. The idea of a unified Central Europe and cooperation has a more or less, mainly liberally supported (slightly conservative) intellectual basis.

Even today, the issue of spatial community is trammelled by historical wounds and conflicts of interest that burden relations formed with states in the area. Relations with neighbouring states are burdened with conflicts related to Hungarian minorities there residing (see: assaults against the Hungarians in Romania; issues related to the restitution, dual citizenship, language use, etc.).

Today interstate conflicts of interest appear within the Central European state community with regard to distribution of the EU funds or gaining economic benefits. "Small Hungarian MNCs" (multinational companies) - such as MOL, Magyar Telekom, OTP or Trigránit - play a vital role, but from time to time they face animosity. These companies expand primarily into the Balkans.

The "near-abroad" of Hungary comprises territories outside the current borders of Hungary that used to belong to the former Hungarian Kingdom. These territories are of vital importance for us because of their proximity on the one hand, and on the other on the grounds of their settlement network that has been formed over a thousand years: transportation routes and places of Hungarian "historical memory". Furthermore, in these territories - inside the Carpathian Basin, outside the borders of the Hungarian Republic - two and a half 
million foreign citizens of Hungarian ethnic origin reside who live within a state apparatus that was once torn out of the Hungarian Kingdom. Over threehundred thousand of them live in the Western Balkans.

Ethnic Hungarians did not occupy all this space even at the time of the Paris Peace Conference in 1920: other nations were living there as well, more or less mingling with each other. In practical terms the sovereignty that was formed in the wake of the Treaty of Trianon received its final shape following the - territorially slight, yet consequentially huge - correction ${ }^{6}$ after the Second World War.

Following this - partly due to the destiny of the Hungarians outside the borders, partly due to spatial community, conflicting and conjoined interests - the relations with the neighbouring states have always been intricate and antinomic, and not without conflicts. Antagonism was a characteristic of the "Horthy" era (1920-1944); even if, for example, in Yugoslav relations - highly significant from the point of view of the present study - the aspiration for cooperation emerged as well.

In the times of state socialism the characteristic attitude was to ignore problems and rein in "nationalism". Crossing the borders was rather difficult, not only westwards but also to other "friendly socialist countries". In Hungary's social and state behaviour some national considerations emerged as well (even though being contradictory) during the march into Czechoslovakia in 1968, and the Romanian village destruction plan of the 1980s. In the period prior to the Romanian Revolution in 1989, the terror of a possible Romanian - Hungarian war precipitated by the ailing Ceausescu regime. The legacy of the obligate period characterized by CoMEcon ${ }^{7}$ and the Warsaw Pact ${ }^{8}$ is the system of recurring conflicts in the interstate relations. The communist party elite having weak inner legitimacy, preferred reaching back to the nationalist political rhetoric of the previous epochs.

$6 \quad$ The so-called Bratislava bridgehead meant the annexation of three Hungarian villages (Dunacsún, Horvátjárfalu, Oroszvár) to Czechoslovakia, which enabled the GabčikovoNagymaros dams to be built, thus forcing Hungary into an exposed position. The construction of the dams and the protests against land degradation on the Danube Bend had a significant role in democratization processes and social transformations.

7 CoMEcon was formed on 25 January 1949 to strengthen economic cooperation between the Soviet satellite states. The organization was dissolved by its member states at the Budapest council session on 28 June 1991.

8 Hungary became one of the founding members of the Soviet-led military alliance - The Warsaw Pact - on 14 May 1955. 


\section{Greater Hungary and national integration}

In the course of ethnic geographical researches conducted following the regime change the picture of a rather slim (compared to Teleki's Carte Rouge ${ }^{9}$ ) Hungarian dwelling place in the Carpathian Basin showed up (Kocsis, K. 1993). Up to now Hungarians have been unable to get over the trauma of Trianon, which manifests itself in their way of thinking as regards Hungarian space and the ideal state. The population of the Hungarians living outside the borders of the country is declining, while some parts of the former dwelling space seem to have been abandoned. This statement is especially true for the Hungarian population in Croatia and Serbia.

Today, there is not a single considerable political organization or power that would hope for the restoration of the territorial framework of the former Hungarian Kingdom or would reckon with the reality of such aspiration. Contrarily to this, foreigners, often visitors from neighbouring countries, are exposed to an endless number of stickers and maps depicting Greater Hungary, prompting absurd territorial demands. The emotional tension manifested this way is a proof of one of the greatest political geographical uncertainties pervading and dividing Hungarian society which also reflects the lack of a national geopolitical concept.

Following the regime change, new elements appeared in relational dimensions such as national-cultural, economic, area development, transportation development, water management, security policy, migratory and other elements. Along with transnational and high-level political relations, new actors turned up observably in the fields of cross-border, inter-territorial relations, civil initiatives and business relations. New issues emerged in the cooperation confrontation dimension. Euro-regional and CBC (Cross-border Cooperation) programmes evolving along the Hungarian borders very often came into existence as forms of "Hungarian - Hungarian" cooperation. These programmes promoted the reintegration processes of the Hungarian communities that had been cut off from the country for decades.

The successful closing of the period got underway with the EU-accession of some countries of the region in 2004 and 2007. The growing dominance of the air borders led to the actual cultural and economic integration of the borderland populated by the Hungarians. Therefore joining the Schengen Area is the most significant EU achievement from a Hungarian perspective. Supporting Romania's efforts to join the Schengen Area, Croatia's EU-accession and the Serbian accession process is a highly important joint venture with the neighbouring countries, which also offers outstanding national political benefits for

$9 \quad$ Count Pál Teleki (1879-1941), geographer and politician (twofold Prime Minister) after World War I, made a map of the distribution of nationalities and population density, where Hungarian ethnic nationality was marked red, hence the name the 'red map'. Although it was of no direct use (during the post-war regularization the exact ethnic distribution was not reckoned with while redrawing the borders), the map still became a household word (ABLONCZY, B. 2005). 
Hungary. Hungarian support given to the integration process of the Western Balkans can mostly be interpreted in this correlation.

\section{Water policy}

Relations with neighbouring countries show new dimensions. The first is linked to the growing priority of water resources, one of the global problems of the twenty-first century. Due to the basin nature of the region, river issues are frequently on the agenda of neighbourhood policy. Waters flowing into a country from the territory of other states have generated numerous conflicts and clashes of interest. Serious incidents from the last few years have highlighted the increasing significance of environmental safety. Here are some examples: the cyanide pollution of the river Tisza (Romanian relevance), floods on the river Tisza (Ukrainian relevance), dams on the Danube (Slovakian relevance, Gabčikovo-Nagymaros Dams), dams on the Drava River (Croatian relevance, Đurđevac), and the pollution of the Raba River (Austrian relevance). The growing number of incidents forecast a new type of international conflicts of the twenty-first century expected in the Carpathian Basin. "Water conflicts" of international relevance are treated acutely at present, but the situation is likely to become more serious.

As rivers flow southwards in the basin, we might reckon with some exposure in our system of Southern, Western Balkan relations. Cross-border funding systems are aimed at joint utilization of natural waters. Earlier the Euroregional programmes, and now the IPA cross-border cooperation programmes, while in the future mainly European Territorial Cooperation, will ensure sustainable development and the fulfilment of common interests (BALI, L. 2012).

\section{International migration}

Another process that affects our international relations is a declining Hungarian population and the opportunities for its supplementation (L. RÉDEY, M. 2001). The population of Hungary has fallen from 10.7 million to under 10 million in the 1980s despite intensifying immigration. Difficulties inflicted by the global financial crisis have cast many employees in a desperate situation: some of these have subsequently appeared as migrants on the international labour market, further aggravating the country's demographic situation ${ }^{10}$. Internal migration threatens some rural areas with depopulation, ageing or becoming a social time-bomb. However, the aforementioned risks are further aggravated by tensions in our city population. Supplementing the declining and ageing population by receiving international migrants from over the borders seems inevitable. This, however, is going to raise further problems in the forthcoming years and decades.

10 The number of people working abroad amounted to some 600 thousand at the end of 2013. As a comparison, in 1956 less than 200 thousand people emigrated, which was then considered to be a huge blow to the country. 
Figure 2: The most typical route of illegal migration to Hungary through the Balkans

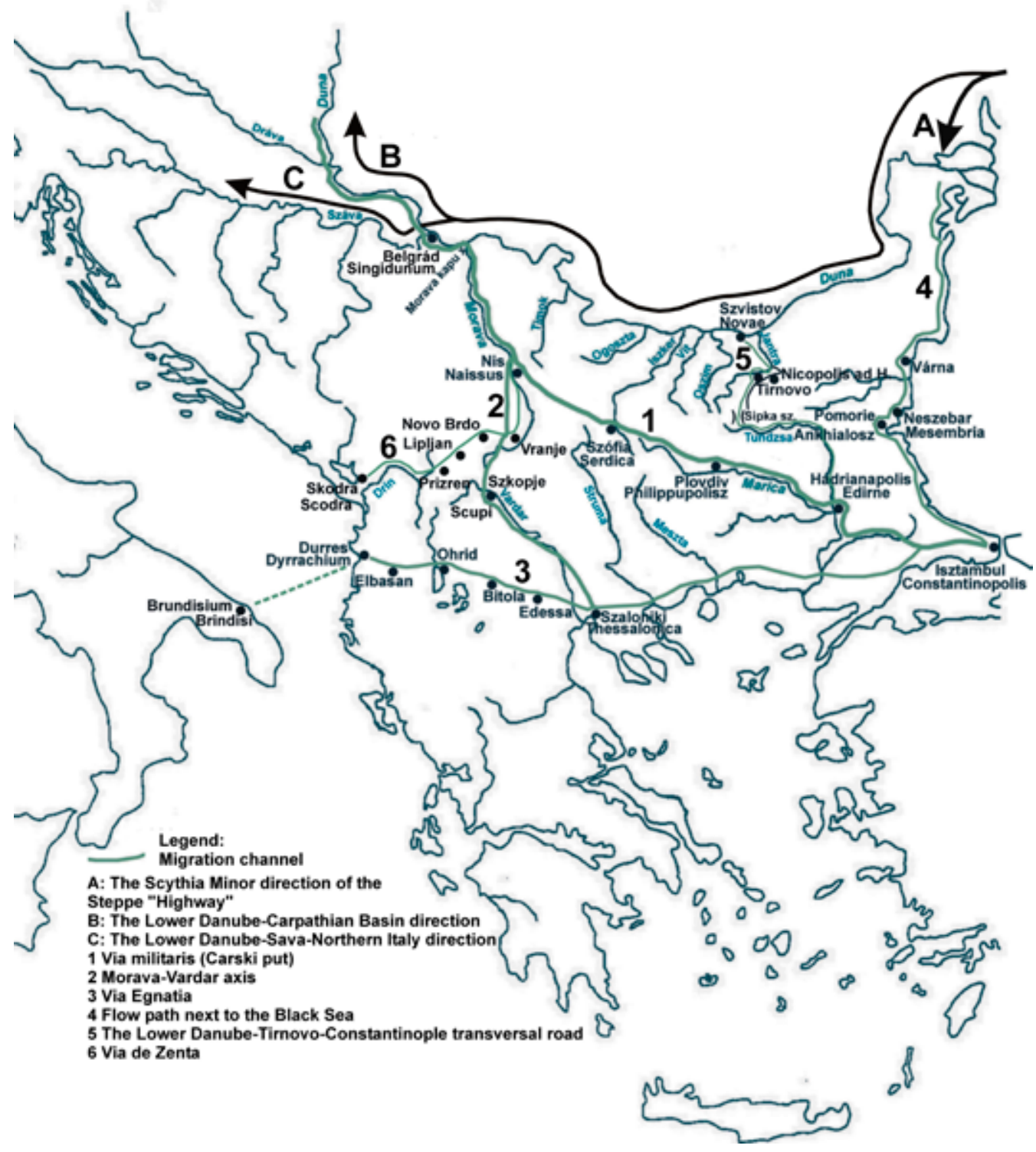

Source: PAP N.-Nagy J. T.-VÉgh A.-LÉPhaft Á. (2013)

Even if we disregard the extremist assumptions, scenarios for 2050 forecast a population size of 8 to 9 million in Hungary. There is not a single forecast that does not envisage hundreds of thousands of migrants coming from abroad. They 
are partly expected from the borderland territories, but great numbers are likely to arrive from the Balkans and the East-Mediterranean territories ${ }^{11}$. Their proportions are debatable, still all forecasts count on the appearance of communities from outside the Carpathian Basin showing strong cultural differences.

Based on religious-cultural features of the potentially sending countries that are characterized by high population growth, it is likely that the majority of the new inhabitants will be worshippers of some form of Islam. ${ }^{12}$ Social and political integration of the youthful, fertile immigrants living in close-knit communities will be one of the most exigent problems. Preparation for this must be started at the earliest possible time. Problems related to social integration in Western European states represent the actual weight of this issue. This prospective best highlights the significance of our system of relations with the Balkans, the Mediterranean and the Near-East region. On the other hand, neither Hungarian society, nor the political elites wish to face this issue for the time being. The situation is worsened by the fact that Hungarian policies are restrictive against migrants and prospective migrants. They make settlement in Hungary difficult even for highly-qualified young people whose affiliation would be a benefit for the country.

\section{Atlanticism}

The estimation of Hungary's size underwent a peculiar change following the dissolution of the Eastern Bloc. Although its area has not changed one square metre, with the dissolution of the neighbouring synthetic states (Czechoslovakia, Yugoslavia, the Soviet Union) it has evolved from a small state into a middlesized state in the region. Compared to other countries of the region - which sometimes got involved in incidents of war or civil war - it has until recently remained an island of peace and predictability.

$11 \quad$ In the first decade following the regime change, immigrants came predominantly from different parts of Serbia and Romania populated by the Hungarians. This is changing nowadays. Mainly the elderly are moving to Hungary from the sending countries, and that is the tendency which does not solve our demographic problems. Younger generations prefer Western European countries, such as Great Britain, France, Spain, Germany and Italy. Many of the immigrants decide to move back. Hungary seems to be losing its appeal as a liveable place offering favourable economic perspectives. If the immigration of the Hungarians from the Slovakian Highlands, Romania and Vojvodina nevertheless continued, cracks within their communities over the borders would inflict significant damages. Thus we cannot say that there is a proper solution to these problems.

12 The estimated number of Muslims living in Hungary was around 30,000 - 35,000 in 2013, mainly living in Budapest. Their largest ethnic group came from various Arab countries (14,000-15,000). The number of (converted) Hungarian Muslims is around 3,000. Their religious centres along with Budapest are Pécs, Szeged, Debrecen and Miskolc (N. Pap, 2013b). 
In October $2006^{13}$ street rallies were sparked off by domestic politics, and violent, sometimes even unlawful intervention of the police demonstrated the end of the years of quiet to the international community. Alongside the intensification of domestic tensions, growing conflicts soon started to dominate foreign relations as well. Hungarian governments became embroiled in conflicts, even with international organizations and some lobby groups with international links.

In relation to the traditional East-West opposition in Europe, Hungary shows clear alliance commitment to the Atlantic (EU, NATO). This, however, does not exclude the sporadic appearance of social indisposition ${ }^{14}$ to American (and British) initiatives. At the same time post-communist Hungarian economic and political wings emerged - often totally renewed and under an international aegis - who are interested in Russian orientation. In the past years this has been demonstrated plastically in reference to energy policy and energy safety. At the same time all-time Hungarian foreign policy must also realize that Russia is its second most important partner after Germany, which requires pragmatic rather than ideological foreign policy between Budapest and Moscow. The Hungarian army sent military corps to various "hot spots" of the Balkans to take part in peace preservation. (Bosnia, Kosovo) Furthermore, it provided the US army with a military base of strategic significance during the Balkan conflict (Taszár).

\section{Energy policy}

Considering Hungary's present size, it is too small to be an independent factor in geopolitical games, and it has rarely been in the focal point of international attention. Examples for this are the Revolution and War of Independence in 1956, where we fought in isolation without comprehending the broader geopolitical situation, or the opening of borders in 1989, which led to the regime change in Eastern and Central Europe. Nevertheless, in both cases the "logic of blocs" manifested itself. Processes had to be adjusted to the geopolitical balance dictated to the broader region.

At present, issues concerning energy safety, gas pipes, distribution systems and storage capacities seem to raise the dilemma of shaping and adjusting. Some kind of logic of blocs is also likely to manifest itself in this case taking the geopolitical balance into consideration, but its outcome is not immaterial to us either.

It is our primary national interest that groups controlling various energy systems consider Hungary as a player of strategic importance and sustain the safety of our energy supply. Energy cooperation has its regional features as well;

13 The speech of Ferenc Gyurcsány, former Hungarian Prime Minister, was meant for his immediate environment, but was publicly revealed and had serious consequences on domestic politics.

14 In Hungary neither Euroscepticism, nor EU-phoria is prevalent, an unconcerned and distant attitude being more typical. The same applies to the country's NATO membership. Concerning international, transnational debates and conflicts the approach of the elites is mostly motivated by ideological and domestic political considerations. 
the Balkans plays an important role in this respect, too: think of Nabucco, the South Stream gas pipeline and Nabucco West, still in the process of planning and negotiation.

\section{Challenges of international security policy}

A number of Hungary-related security policy challenges are connected to the Balkans, the Near East and Central Asia. The territorial patterns of these areas are linked to Spykman's conception of the "Rimland" and its centre of gravity is situated south of Hungary. From the point of view of security policy, Hungary belongs to the Southern wing of NATO. In the last two decades our diplomatic activities have comprised predominantly the treatment of problems in the Western Balkans. Alliance commitments require the deployment of a contingent of approximately 1000 people abroad. These corps are serving in the Balkans, the Near East and Central Asia; furthermore, they will soon be present in the crisis-affected areas of Africa. In the latter territory the expansion of Chinese oil corporations creates uncertainties in safety and conflicts, while Islamic fundamentalism provides a breeding-ground for terrorist organizations. Moreover, the emergence of refugee waves reaching Europe must also be prevented. We might be affected by these influences, especially via Southern Europe and the Balkans. As a member state of the EU we must form an opinion in numerous issues we have never taken a stand on before.

In our view, the greatest problem does not lie in our military skills or financing the operations. It rather revolves around the questions of how to prepare soldiers for operations in faraway lands and how Hungary could benefit in both moral and financial sense - from the accomplishments of the missions.

In this politically exposed situation the Balkans will probably remain a primary region in terms of our security. Even if no threat is imposed by this region in the form of interstate conflicts as in the 1990s, it will rather constitute modern political security challenges, such as organized crime, arms trafficking, human smuggling, gaining ground of terrorist groups, etc.

We must also prepare for extraordinary situations that might be connected primarily to the escalation of the political crisis in Bosnia and Herzegovina, ethnic tensions in Southern Serbia, to Kosovo or the issue of Western Macedonia. There are other places in the Balkans that might generate further unexpected conflicts. Such are Bulgarian territories populated by Turkish, Pomak and Gypsy ethnic groups, the Northern borderland in Greece, the Greek populated parts of Southern Albania, dwelling-places of Sandzak Muslims and ethnic Albanians in Montenegro and Serbia (NÉGYeSI, J. - PAP, N. 2013). 


\section{The Balkans and its wider environment in Hungarian foreign political thinking}

\section{$1920 / 2004$}

Hungarian foreign political thinking has often changed in the past centuries according to the demands and influence of great powers, and partly internal interests. In the formation of foreign relations, the years of $1920^{15}$ and $2004^{16}$ are important turning points that are connected by more than a superficial resemblance. The decree of Trianon shrank the borders of the new-born independent Hungarian state, leaving it long in the grip of a hostile state. After World War II it was obliged to join the Soviet bloc, which meant a formerly inconceivable degree of revaluation of Eastern relations. The EU-accession in 2004 put an end to this era through processes that started with the regime change, and in many respects the elbow-room in Hungary's foreign relations became similar to that of the pre-1920s.

The main direction of political thinking in 1989-90 turned towards the West as a counteraction to the former Eastern orientation, bringing about our involvement in Euro-Atlantic integration. However, beyond the general concept of Western orientation not a single group of the political elite drew up a strategy on shaping foreign policy, foreign economy and foreign relations in the broader sense. The Central European system of relations was more or less reconstituted by the formation of the "Visegrad" cooperation (and partly by CEFTA). However, the effectiveness of the cooperation within the framework of the Visegrad Group (V4) fell short of expectations. At the same time it could not utilize its Southern system of relations which boasts the past and present that underline its significance. Although relations existed, they lacked vision and strategy. Official relations were shaped both by traditions and ad hoc goals. The structure of Hungarian foreign policy - unlike the practice in earlier historical times - was based on the follower strategy typical of the state socialist era. This meant suffering and avoiding possible influences rather than active shaping of events.

In the first centuries of Hungarian history the foreign policy of our kings had visions related to goals concerning the Balkans and the (partly connected) Italian territories. Beyond these, however, there was an unknown world. The Habsburgs and the elite of the Austro-Hungarian Monarchy had conceptions about the Mediterranean world and also related political goals. The Hungar-

The Treaty of Trianon was signed on 4 June 1920, closing World War I. Hungary lost two thirds of its territory and population.

16 Hungary was one of the ten countries that joined the European Union on 1 May 2004. Eight Eastern-Central European states became EU members: Czechoslovakia, Slovakia, Slovenia, Poland, Hungary, Latvia, Lithuania and Estonia together with two Mediterranean islands, Malta and Cyprus. 
ians, however, never did. It was because there were no challenges from this region that had to be addressed.

In 2004 a new situation emerged due to our accession to the European Union, which has one of its most important neighbouring territories around the Mediterranean Sea. None of the member states of the EU can afford not to have a policy related to the Mediterranean region without suffering (financial and moral) losses. In the last few years this region (Southern Europe, together with the Southern and Eastern shores of the basin) has been re-valued both in terms of challenges and of opportunities.

Although northern countries lying on sparsely populated, politically safe less frequented territories extended the Northern dimensions of the EU during the accession in 1995, the southern, much more densely populated, and in terms of population more dynamic territories with a number of safety risks or significance were constantly being re-evaluated both for NATO and the EU. As a comparison: the three states (Austria, Finland, Sweden) that joined the EU in 1995 have a total population of 22 million, 14 million of which only belong to the Northern countries. The Eastern expansion of ten member states (eighth of them from the post-socialist bloc) in 2004 is of great significance; it means over 72 million people and the significant eastward expansion of the EU. The two tiny Mediterranean island states have strategically significant locations. Through the integration of the southern part of divided Cyprus a security related political conflict became incorporated into the EU as well. With the expansion to the Balkans in 2007, Romania with its population of 22 million and Bulgaria with a population of 7 million established military bases increasing their weight in the security based political cooperation with regards to the Near East. With their accession, the legitimacy of the territorial category of the Western Balkans gained strength and, being a huge, problematic enclave, it has attracted European political attention following the expansion of 2007.

The region in the Mediterranean geopolitics

What are the main reference points along which our interests can be defined? Following centuries of peripheralisation, the Mediterranean Basin has been re-evaluated in recent decades. Strategic sea routes gained a new meaning during the times of East-West antagonism. The Atlantic powers established military bases on the islands and the southern shores in support of Europe facing the Soviet threat. In 1952, following a bitter civil war, Greece joined NATO instead of the Soviet bloc.

In Northern Africa there are huge mineral oil- and natural gas reserves. Apart from that, the Mediterranean (and the Balkans) has become one of the most important areas for the distribution of hydrocarbons. Political conflicts of the "Arab spring" in Northern Africa (Algeria, Libya, Egypt and Tunisia), and the crisis in the Near East (Palestine, Syria, Lebanon, etc.) affect global energy 
safety. Therefore, all stable powers are concentrating their focus and strength in the region. The significance of the region might further increase in the future. The construction of gas pipes linking the Near East, Inner Asia and Europe has an effect on the Balkans as well. Violent acts that have escalated in some countries jeopardize general safety, additionally inducing further waves of refugees and thus weighing on the problems of European countries.

This is a part of another, long-existing important issue: migration through the Mediterranean "Rio Grande". The welfare systems and job prospects of Europe and hope for a better life motivate millions to set off. This has already resulted in numerous severe conflicts and draws the EU's attention to the region with reason: the Euro-Mediterranean partnership programme, run with significant financial support, aims to partly mitigate these phenomena and their influences.

In the last few years French politics has increased its activity again with its plan for a Mediterranean Union and by offering a perspective of cooperation to Islamic countries. Political Islam is gaining ground in numerous countries of the Southern Mediterranean region, which is considered by many as a threat to the states and societies of Western civilization, attacking their life-style and pointing out their vulnerability (e. g. in energy supply). The sweep of Islamic fundamentalism in the Balkans, more precisely in Bosnia and Herzegovina, Macedonia, Bulgaria and the Sandzak territories, has become an important item on the political agenda.

Hungary, as a NATO- and EU member state, takes its share of the responsibility with regard to security, political and economic issues of the Balkans and the Mediterranean region. It is active in peacekeeping operations in a number of world regions. It is a financier of the Mediterranean policy of the EU and also of the international aid and development initiatives in the Balkans and Northern Africa.

"Eastern opening", the new doctrine of Hungarian foreign policy

The centre-right government (FIDESZ-KDNP party alliance) that gained power in 2010 has started "revolutionary" changes on the basis of a two-thirds majority in nearly all fields of Hungarian society and politics. Foreign policy was not an exception.

The three pillars of Hungarian foreign policy following the regime change were the EU membership, NATO alliance and neighbourhood policy, emphasizing the minority issue. The new concept was originally called "global opening" for internal use, and "Eastern opening" in a wider spectrum of use to highlight its emphasis, which indicated something new in the terminology.

According to the new doctrine in Hungarian foreign political thinking due to global changes (among which financial crisis plays an emphatic role) there is a demand for newly based and much stronger relations, primarily with BRICS 
countries, but with other emerging - among them Central Asian - countries as well ${ }^{17}$. This is partly traced back culturally to the Eastern origin of the Hungarians and the often inherent mutual sympathy with some Asian peoples. Among these countries Turkey, as a dynamic actor, plays a significant role, taking the role of a Euro-Asian intermediary among other things.

Turkey as a NATO member state with a population of nearly 75 million has become a significant military, and a major economical power. Also it is knocking harder on the door of Europe as regards policies on Europe, the Near East, the Caucasus, the Balkans and the Mediterranean region. The significance of its role in the decades-old conflict of world political relevance connected to Palestine territories is increasing, as lately it seems to be moving away from Israel and drawing nearer to the public feeling of the Islamic world. Its presence in the Balkans has intensified, and it is especially active as regards Bulgaria, Bosnia and Herzegovina, Albania and FYROM - the Former Yugoslav Republic of Macedonia. In the forthcoming decade Turkey is expected to become the strongest economic, political and military power of the region, meaning that it cannot be ignored by Hungary either. The currently ruling Islam-friendly AKP that created legitimacy in the Ottoman times now utilizes the increased margin for drawing up a new foreign policy. From Afghanistan to the "Horn of Africa" and concerning Hungary it has become active and is in the process of reshaping and strengthening its relations. This can be easily harmonized with the Hungarian policy of "Eastern opening". Thus the Balkans might be an important side scene of the new doctrines, as it might appear a primary terrain of Hungarian - Turkish cooperation. Turkey has such political weight in security and economic matters in the South-Eastern system of relations that influences not only the Western Balkans, but Central Europe as well. Due to Ankara's increasing regional role as a powerful monolith, this can be considered as not only conjunctural but permanent.

"Eastern opening" also proposes the re-consideration of the existing relations with our partners. Lately there have been delicate modifications in the concord between the old and new members of the European Union and NATO. Despite difficulties Germany's relative European weight has increased in the midst of the world economic crisis but it does not play an independent role or only within strictly defined limits. Italy's importance has weakened due to intense domestic political divisions and a decline in competitiveness. Of the new member states, Poland has gained in importance due to its geopolitical situation. Of the older states it is Spain that - looking back at a prosperous nearpast, but facing severe financial problems now - has an essential role to play. The United Kingdom, although it seemed to draw away from the continent with

17 The development of Eastern relations features the accentuated role of the countries like China, Turkey, Kazakhstan, Georgia, Vietnam, Azerbaijan, Saudi-Arabia, Kuwait as one of the smaller states of the Persian Gulf, etc. 
its unconditional friendship with the US at the time of the Gulf War, has preserved its weight for the time being. France continues to play a primary role but its relative weight seems to be decreasing on the continent. All these balance shifts also influence our Balkan and Eastern policy. As regards the Western Balkans, member states of the European Union are divided. In this situation Hungary has ample elbowroom and is a subject in EU discourses. When it is in our interests we support the EU accession of the countries in the region, as well as all initiatives that strengthen regional stability.

Public opinion in Hungary and our political elite know little about the Balkans, our knowledge deficiency being considerable. The region plays an essential part in nearly all the major challenges (security environment, water- and migration policy, foreign economic margin, etc.) that the country is facing. The latest documents prepared in government workshops acknowledge its significance and importance. This era challenges us to learn to use multilateral political tools in order to be able to enforce our interests.

\section{Literature}

- Ablonczy B.(2005): Teleki Pál. Osiris Kiadó, Budapest, 547 p.

- BALI, L. (2012): The major political aspects of the croatian-hungarian relations in the changing geopolitcal space, in thearpathian-Balkan Region. In: (ed.) Petric H.-Feletar D. 2012. Podravina Casopis za multidisciplinarna istrazivanja. XI. évf. 21. szám. Samobor pp. 26-35.

- Kitanics, M. (2008):The Hungarian-Balcanic relationships from the beginnings to recent years. In: Yамамото, A. (ed.) The Hungarian Cultural Diversity Research Group (ed.), Joint Research with the University of Pécs for the Preservation and Development of Cultural Diversity I., Graduate School of Humanities and Social Sciences, Nagoya City University, Nagoya, pp. 51-58.

- Kiss J. L. (ed.) (2003): Globalizálódás és külpolitika. TLA, Budapest, 298 p.

- Kocsis K. 1993: Az etnikai konfliktusok történeti-földrajzi háttere a volt Jugoszlávia területén. TLA, Budapest, 78 p.

- MAKKaI, L. (1942): A magyar Balkán kutatás szervezési kérdései. In: Gál I. (ed.): Magyarország és a Balkán. Budapest, pp. 71-78.

- Gulyás L. (2012): Küzdelem a Kárpát-medencéért. Kárpátia Stúdió, Budapest, 283 p.

- L. RÉDEY M. (2001): Demográfia. ELTE Eötvös Kiadó, Budapest, 191 p.

- Négyesi J. - PAP, N. (2013): Hungary's role in the Western Balkan Security Process.In: Lőrincz, A. (ed.): The Balkans Dialogue: Conflict Resolution and EU Accession Politics in the Balkans and Turkey.Budapest, pp. 202-208. 
- Pap N.(2013): Hungary, the Balkans and the Mediterranean. Publikon, $210 \mathrm{p}$.

- Pap N. 2013: A pécsi szunnita muszlim közösség. - Kisebbségkutatás 2013/3-4.

- Pap N. 2013: A muszlim közösségek szerveződésének sajátosságai KeletKözép-Európában. - Civil Szemle 2013/2. pp. 49-65

- PAp N.-Nagy J.T.-VÉgh A.-LÉPhaft Á. (2013): A magyarországi muszlim migránsok az információs társadalomban. - Információs Társadalom 2013/3-4., pp. 59-78. 
Prof. dr Norbert PaP, vanredni profesor,

Geografski institut, Univerzitet u Pečuju, Mađarska

Máté Kitanics, doktorand

Geografski institut, Univerzitet u Pečuju, Mađarska

\section{MAĐARSKA I BALKAN}

\section{S a ž e t a k}

Za Balkan, Mađarska predstavlja jedan od regiona posrednika u Evropi. U isto vreme, Balkan je teritorija spona između Turske, danas regiona u usponu, i Mađarske, koja

nastoji da sarađuje sa njim. Budući da je Mađarska član NATO i Evropske Unije, ona učestvuje u geopolitičkim igrama koje postoje između Evropske Unije, Rusije, SAD i nekih zemalja islamskog sveta. Ovo učešće suštinski određuje zadatke Mađarske spoljne politike, kao i zadatke njene kulturne, ekonomske, i politike bezbednosti i odbrane u sledećim decenijama.

Mađarska predstavlja kapiju između Zapadne Evrope i Balkana. Ova uloga bila je dominantnija u prethodnim vekovima mađarske istorije nego što je to danas, ne samo zato što su veličina i snaga ove zemlje značajno opale posle Trijanonskog sporazuma. Mnogi od istorijskih, imperijalnih refleksasu se zadržali, ali bez imperijalnih pretenzija. Danas smo samo jedan od regiona posrednika koji ima uspostavljene odnose sa Balkanom i čini most ka Evropi. Ubrzane promene svetskog poretka, zemlje BRIK grupe, kao i nastanak nekih važnih država srednje veličine, poput Turske, znače neizbežno prilagođavanje naše zemlje. Na tome se zasniva politika 'otvaranja ka istoku'.

Ključne reči: Mađarska, Balkan, geopolitika, migracije, Dunav, 'otvaranje ka istoku 